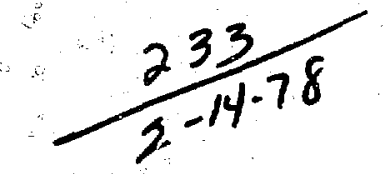

th.1832

UCRL-52335

$+1$

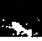

\title{
CORRELATION OF ALLUVIAL DEPOSITS AT THE NEVADA TEST SITE
}

Brian Grothaus

Nancy Howard

September 30, 1977

Prepared for U. S. Department of Energy under contract No. W-7405-Eng:48

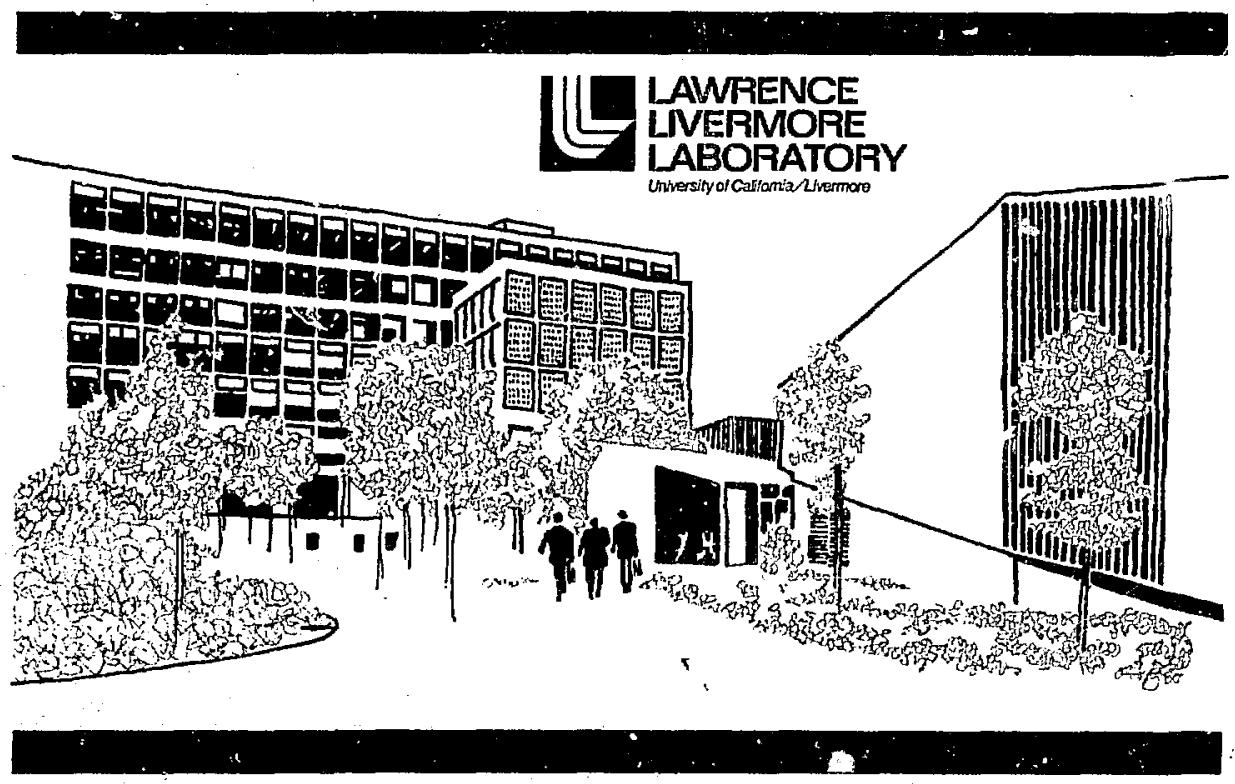




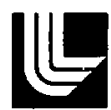

\title{
LAWRENCE LIVERMORE LABORATORY
}

University of Caltomia/Livermore, Califomia/94550

UCRL-52335

\section{CORRELATION OF ALLUVIAL DEPOSITS AT THE NEVADA TEST SITE}

\author{
Brian Grothaus* \\ Nancy Howard
}

MS date: September 30, 1977

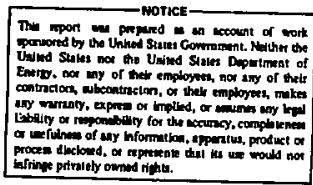

*Present address: University of South Carolina, Columbia, SC. 


\section{CONTENTS}

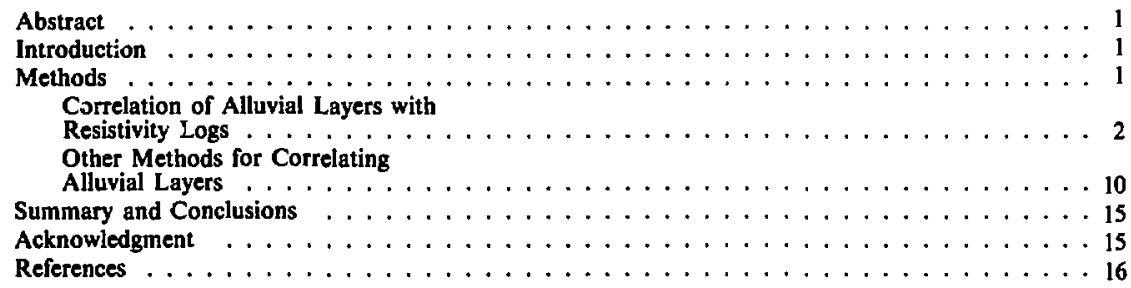




\section{CORRELATION OF ALLUVIAL DEPOSITS \\ AT THE NEVADA TEST SITE}

\section{ABSTRACT}

Because characteristics of rock layers and problens in drilling must be studied before radioactive waste can be safely contained, an evaluation was made of methods for correlating alluvial deposits at Yucca Flat of the Nevada Test Site(NTS). Although correlation of Tertiary volcanic tuff beds at the NTS has been successfully achieved, correlation of stratigraphic zones in the overlying alluvium has posed technical difficulties. We have evaluated several methods for correlating alluvial deposits from drillholes, including electric resistivity logs (E logs), visual examination of sidewall samples and comparison of their carbonate $\left(\mathrm{CO}_{2}\right)$ content, downhole stereo photography for identifying debris flow deposits, caliche age-dating, and specific yield and permeability measurements of deposits. For predicting the thickness of zones having similar physical properties in the alluvium, E log measurements were found to be the most useful of these methods.

\section{INTRODUCTION}

The late Tertiary and Quaternary colluvial and alluvial deposits at the Nevada Test Site (NTS) consist predominately of waterlaid sands and gravels with occasional debris-flow deposits. The alluvial deposits in this area are comprised of mainly Tertiary volcanic tuffs and Paleozoic and Precambrian clasties and carbonates.

A major task of persons responsible for the containment of radioactivity from underground nuclear explosions at the NTS has been to correlate stratigraphic zones in the alluvium that possess similar physical properties (e.g., $\mathrm{CO}_{2}$ content). This is done so that the physical-chemical characteristics of rock layers can be predicted. In turn, more accurate forecasting of potential drilling problems will be possible at proposed sites. A knowledge of the alluvial stratigraphy and its correlation will also help us to better understand the geologic history of Yucca Flat.

Correlation of the overlying alluvium in the northern part of Yucca Flat has posed considerable technical difficulties. In this study, we have reviewed the applicability of resistivity $\log$ data for correlating zones of alluvial deposits, and explored the potential of other methods of correlation, some of which have been successfully used by others elsewhere. For this project, we studied Area 2 of the NTS (Fig. 1). It lies in the north-central portion of Yucca Flat, and is bordered on the east by Yucca fault and on the west by the Carpetbag fault. West of the Carpetbag fault is a north-south subsurface ridge of Paleozoic rocks covered by less than $250 \mathrm{ft}$ of alluvium in some places (Fig. 2). ${ }^{1}$ We obtained our daia from the deposits in holes drilled east of this ridge where the alluvium abruptly thickens.

\section{METHODS}

A wide variety of data were used for correlating alluvial deposits: electric resistivity logs (E logs), gamma-gamma density logs, lithologic descriptions from sidewall samples and downhole photos, and $\mathrm{CO}_{2}$ analyses from sidewall samples. The best results were obtained by examining both electric 


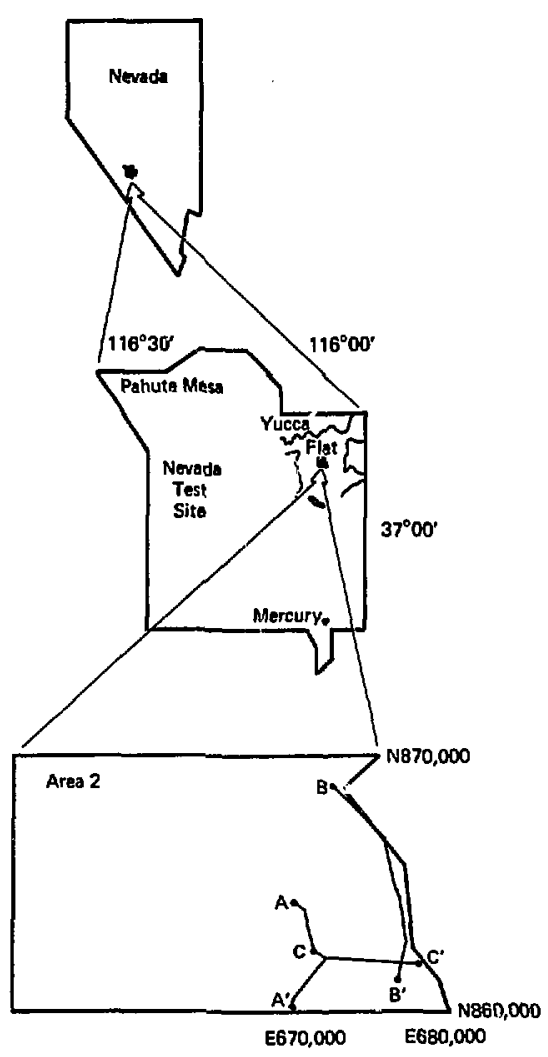

Fig. 1. Location of Area 2 near Yucen Flat of the Nevada Test Site showing the three cross sections studied by authors. Numbers around the map are Nevada coordisates.

logs and sidewall phoius. Unfortunately, the investigation was limited to the few holes where alluvial resistivity was logged and to the scattered depth intervals from which sidewali photos were taken.

\section{Correlation of Alluvial Layers \\ With Resistivity Logs}

\section{Examination of Electric Logs and Sidewall Samples}

In correlating the alluvial stratigraphy at NTS, our best results were achieved with $E$ logs. The logs used were plotted with a 5 -ft smoothing interval, and were correlated chiefly by a "best fit" method. This method is an overall comparison of one $\log$ to another by sliding it to meet the other until the best fit for the resistivity curves is achieved. The alluvium surface and the tuff-alluvium contact were the only real datum planes that could be used because there are no distinctive continuous marker horizons within the alluvium itself. Nevertheless, the curves do match up well in many cases. The problem, however, is in understanding what these traceable zones of matching resistivity actually indicate.

In working with $E$ logs from oil and coal fields, there is usually no major problem in identifying the rock types (sands, shales, carbonates) before correlating them. Subsequently, when correlating the data, one can envision how the stratigraphic profile should look on the basis of paleoenvironmental models, and a more accurate picture of the subsurface can therefore be made. At the NTS, we are not working with well-defined rock types, but rather an agglomeration of volcanic, nonvolcanic clastic, and carbonate fragments. On E log traces, it is therefore difficult to know the lithologic differences between peaks even though they can often be traced from one hole to another. One should therefore construct lithologic models from such correlations with caution.

Originally, it was thought that the problem of correlating predominant layers could simply be solved by making preliminary correlations with the $E$ logs and then examining the sidewall samples to determine the actual causes of the zones with comparable resistivity. It was hoped that carbonate pebble layers, silty zones, and other distinct layers would show unique resistivity signatures, and once these were established, the units could then be recognized simply by analyzing the $E$ logs. After examining a large number of samples, this was found not to be true. If there are distinci changes in the lithology where these kicks occur, they are not readily distinguishable by visual analysis of the sidewall samples. Possibly, x-ray diffraction analysis would show imperceptible mineralogic differences.

There are several explanations for this apparently poor correlation between resistivity curves and samples. Rather than distinct changes in rock type, the E logs may be primarily affected by diagenetic effects such as varying degrees of clay alteration or zeolitization of the tuff fragments. A marked response of resistivity logs to the degree of alteration has been demonstrated in the underlying tuff. Perhaps the dominant factor governing the resistivity of alluvium is its proportion of tuff and, 


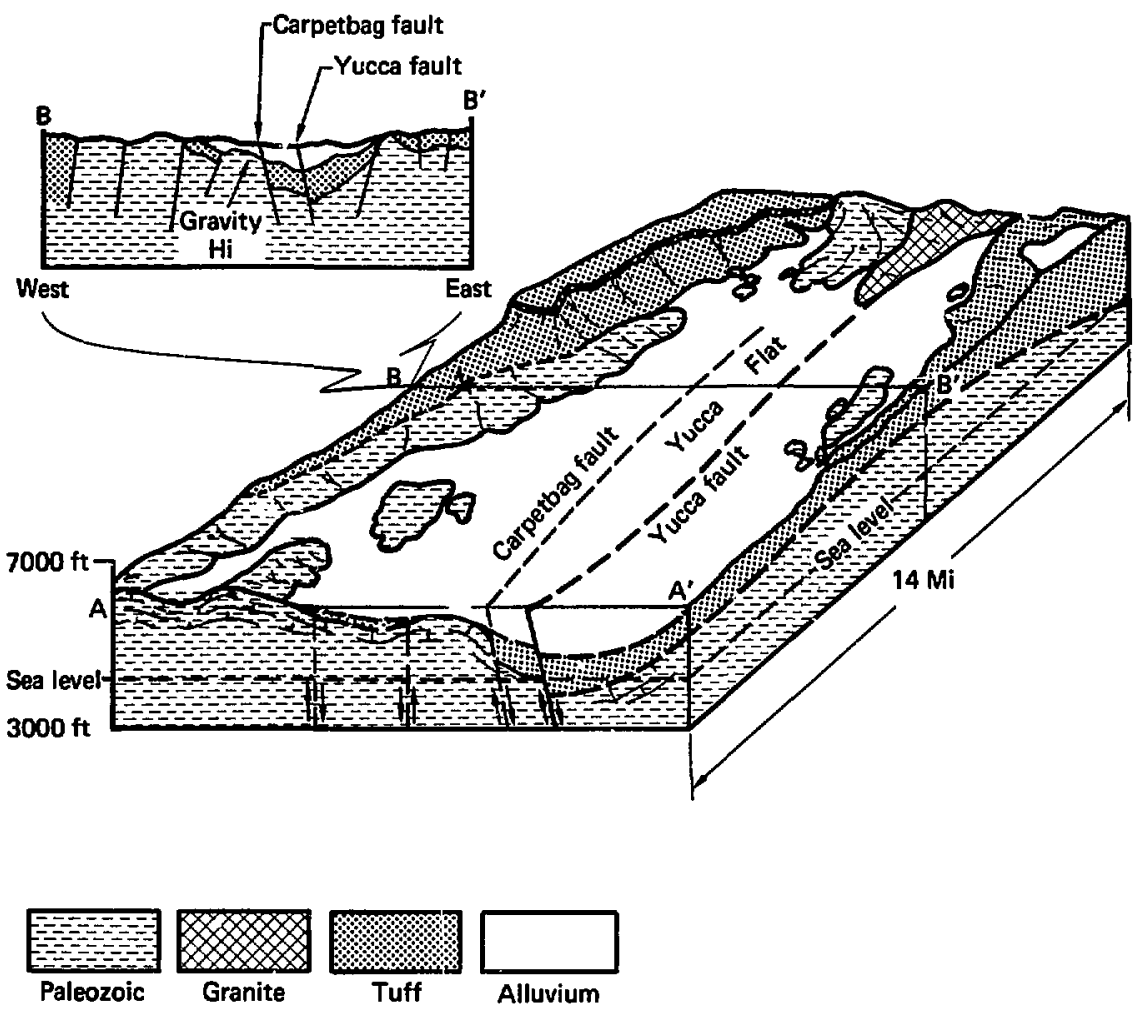

Fig. 2. A three-dimensional dingram of the northem portion of Yucca Flat showing major faults and rock layers. Insert shows horizontal section of B-B' cross section.

more importantly, the percentage of altered vs unaltered tuff. Limited examination of samples with a binocular microscope has not confirmed this. If the amount of tuff does contribute to alluvium resistivity, enalysis of $x$-ray diffraction patterns together with $\mathrm{E}$ logs may be the best method of correlating deposits.

However, E logs may reflect other changes that are not identifiable in the sidewall samples. Alluvium consists largely of loose gravels, representing many rock types in varying proportions. Many of the sidewall samples may not be representative of alluvium since they consist only of a cup full of sand-sized alluvium and several small pebbles. In obtaining sidewall samples, the sampler is lowered to a known depth, but it often does not catch the side of the hole immediately. Sidewall photos from the same depths indicate that the sampler often scrapes the wall for several feet rather than taking a sample from a specific point. Through examination of sidewall samples and photos, we may produce a detailed lithologic description. No matter how accurate the description is, however, its accuracy is only as good as a sample is representative of the level from which it was taken. At one extreme, the sample may be perfectly representative, while at the opposite extreme, the sample may have been taken only from one boulder set in a different matrix. Also, the sample may consist only of matrix if the pebbles are too large for the sampler. If 
possible, stereo photos should be taken within the hole to enable one to determine how representative the sidewall samples are.

The E log resistivity curves probably represent the interaction of many factors. When logging holes in unsaturated material like the alluvium at the NTS, porosity is the main determinant of resistivity. However, the degree of porosity is governed by such variables as lithology, grain size, particle sphericity, orientation, sorting, sediment compaction, fracture zones, and cementation. Therefe.e, although the sidewall rock samples or photos may be used in some ways to correlate alluvial strata, they are difficult to correlate with actual resistivity values.

\section{Trends in Resistlvity Loys}

Comparing $E \log$ values with sidewall samples does not always indicate a correlation: between the two, and it is therefore difficult to assess bow sensitive $E$ logs are to detecting small-scale lithologic and tex/mrol changes (boulder beds, silt layers, etc.). However, they may be used in a broader way to infer relative changes in density and saturatio:.

Examination of approximately 40 resistivity log plots from Area 2 has shown that the overall profile of the resistivity curve is broadly convex to the right (Fig. 3). Although this is a widely recognized phenomena, there does not seem to be any generally accepted explanation for why this occurs. In working with average water content, grain density, and bulk density values, Germain also observed a similar zonation with depth in alluvium. The zones he defined-the surface down to about $800 \mathrm{ft}, 800$ to $1100 \mathrm{ft}$, and below $1100 \mathrm{ft}$-correspond well to the major inflections in the resistivity curves.

In isspecting Germain's data, we found that down to $\sim 800 \mathrm{ft}$, the grain density gradually decreases with depth, and the water content reaches a minimum at $\sim 600 \mathrm{ft}$. Over the same depth, bulk density increases to a maximum between 700 and $800 \mathrm{ft}$. This produces a decrease in porosity and ccrresponding increasc in saturation with depth. From 800 to $1100 \mathrm{ft}$, the grain and bulk densities decrease with depth while the water content and porosity increase. Below $1100 \mathrm{ft}$, the densities are fairly constant, the water content continues to increase slowly, and the por sity increases slightly.

The high degree of correlation between this zonation based on physical properties and the bowshaped resistivity profiles commonly observed in Area 2 electric log traces indicates that the interaction of water content, grain density, and bulk density values is likely the most influencing factor in determining the main changes in resistivity with depth. If this is true, the zonal interactions ariong these 3 parameters is probably universal throughout Area 2.

\section{Cross Sections}

Three cross sections have been prepared for Area 2 based upon digitized $E$ logs (Fig. 4). Two of these, $A-A^{\prime}$ and $B-B^{\prime}$ (Figs. 5 and 6 ), are north-south profiles, whereas $C-C^{\prime}$ is oriented east to west (Fig. 7). Although only those $\mathrm{E}$ logs that have been digiaized were actually incorporated into these cross section?, all other pertinent exploratory and emplacement holes for which resistivity data exists were used in determining the final correlations.In Figs, 5-7, question marks were placed at those portions of the cross sections where there is either a lack of data, or where it is difficult to correlate the data without further information.

As we illustrated in Fig. 3, many of these logs possess a similar pattern in the overall resistivity with depth. On a smaller scale, however, there is considerable fluctuation in the resistivity values, and this can also be correlated. If one were working with $\log$ data frem more conventional sand and shale sequences, thê.ie small scale changes could be used to pick beds where there are lithological changes. The continuity of various major rock types could then be traced between holes. In dealing with alluvium, however, these small-scale changes cannot be assigned to a particular lithology because the material has a complex composition and texture. Therefore, the correlation lines between holes shown in Figs. 5-7 do not necessarily mark boundaries between beds or distinctive lithologies. Such lines represent only distinct horizons characterized by similar resistivity patterns and have been chosen because it is easy to recognize these horizons from one hole to another. Since the exact reason for these comparable peaks is not fully understood, we cannot effectively evaluate the accuracy of these correlations; however, they do appear to be strikingly continuous with only minor changes occurring over the area we examined.

In cross section $\mathbf{A}-\mathbf{A}^{\prime}$, the resistivity profile from drillhole U2dy (far right, Fig. 5 ) is especially difficult to correlate with the other logs because of the small variation in resistivity with depth. Examination of other resistivity data ind'cates that this is probably due to probiems enco \&ntered during logging and does not necessarily reftect major changes in the alluvium. Hower:- geologic cross sections also indicate a fault th.t say extend through the tuffs into the alluvium of U2dy at $\cong 430 \mathrm{ft}$. This may further account for the difficulty in trying to correlate this drillhole with the adjacent one, U2do. 
An average resistivity log for

Area 2
Zonation observed by Germain (1976) in areas 2 and 10.

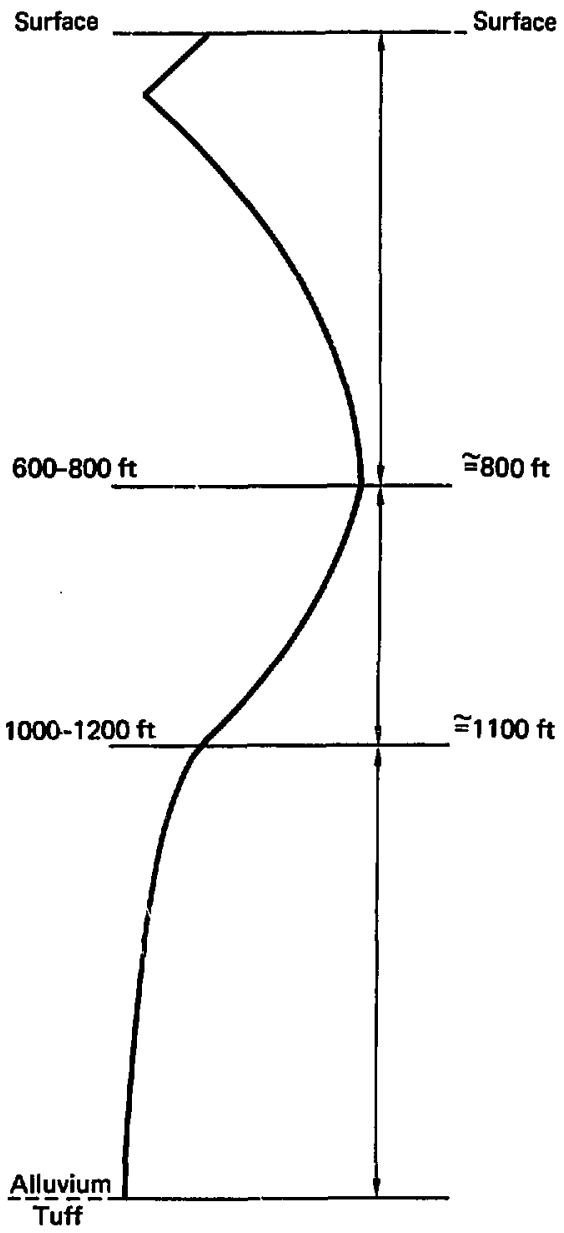

- Grain density and water content approximately constant; some tendoncy for grain density to fall with depth.

- Shallow minimum in $\mathrm{H}_{2} \mathrm{O}$ content at I600 ft.

- Bulk density increase with depth, peaking $\approx 700-800 \mathrm{ft}$.

- Decrease with depth in porosity and gas filled porosity.

- Grain and bulk density decrease rapidly with depth, while water content increases.

- Porosity increases sharply with depth; saturation and gas filled porosity flatten out.

- Densities remain cons:stent for several hundred feet, but fall as water table is approached; $\mathrm{H}_{2} \mathrm{O}$ content increases with depth until effect of static $\mathrm{H}_{2} \mathrm{O}$ level is felt at about $1800 \mathrm{ft}$.

- All these changes appear to cancel out in that saturation and gas-filled polosity are constant while, porosity increases somewhat with depth.

Fig. 3. Profile of resistivity surve from $\log$ plots of Area 2 of the NTS.

In cross section B-B', hole Ue2ek (far right, Fig. 6) is equally difficult to correlate with adjacent holes, but this is because it is an induction $1 s_{5}$. ' In in a dry hole as opposed to the others, which are run in svet holes. Nevertheless, there do not appear to be any major faults closely associated with U2ek. Based upon these correlations, inspection of al! three resistivity profiles in Figs. 5-7 indicates that the alluvium is generally continuous since no major offsets from faulting are apparent, except fur U2dy. 


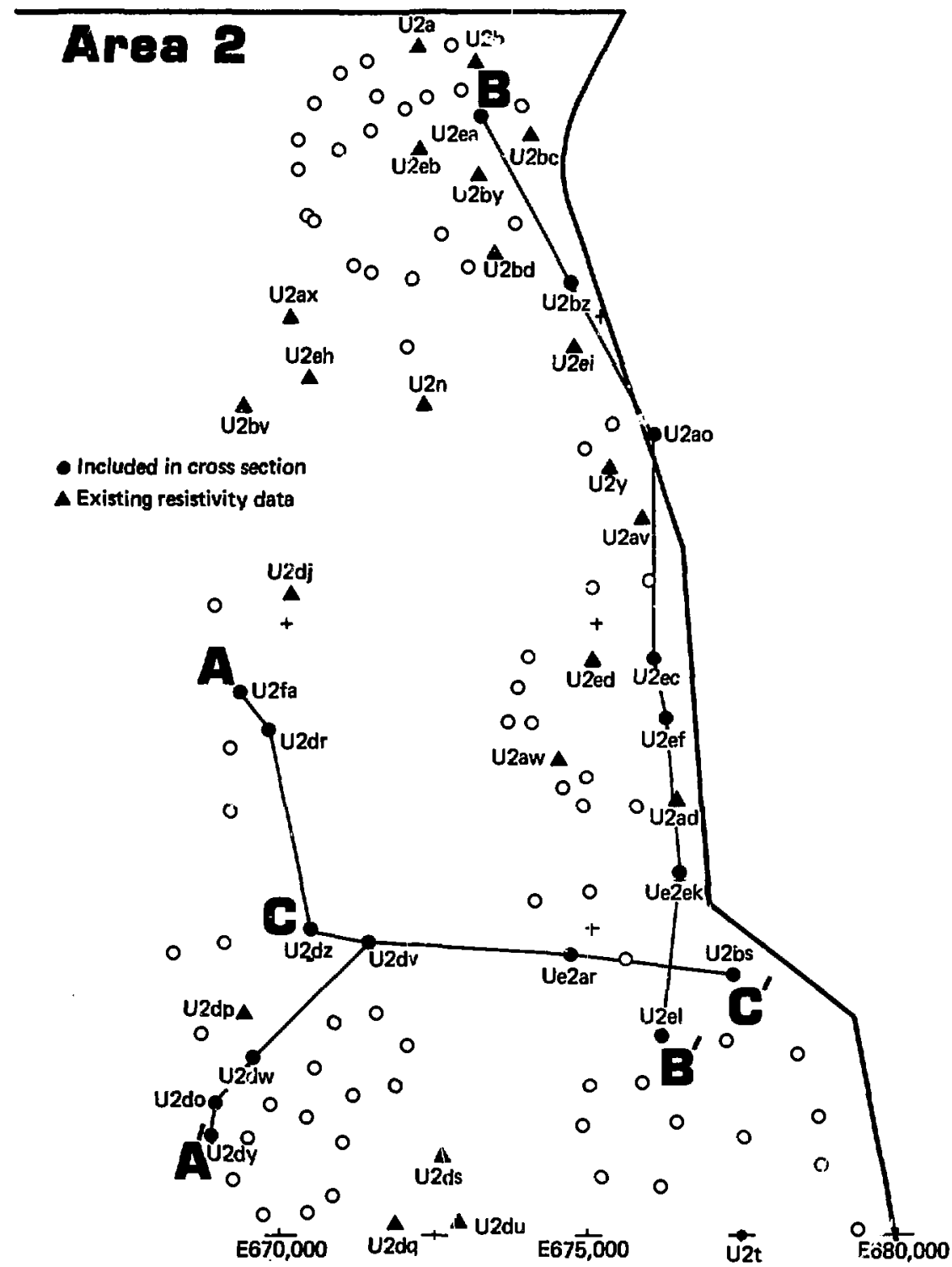

Fin. 4. Location of toreloles studied in this report. Lines connected by letters represent the cross sections studie $J$ in this area. Open circles repiesent boreholes not yet invesilgated. 


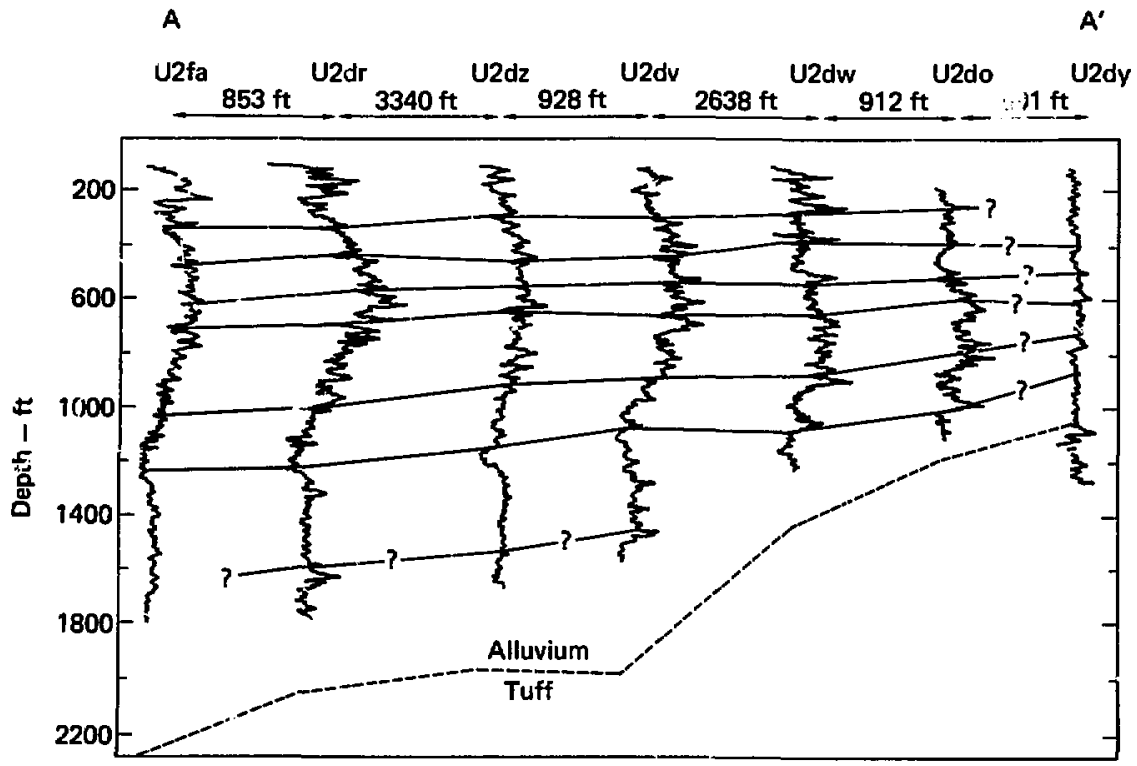

Fig. 5. Resistivity profiles from boreholes along cross section A-A'.

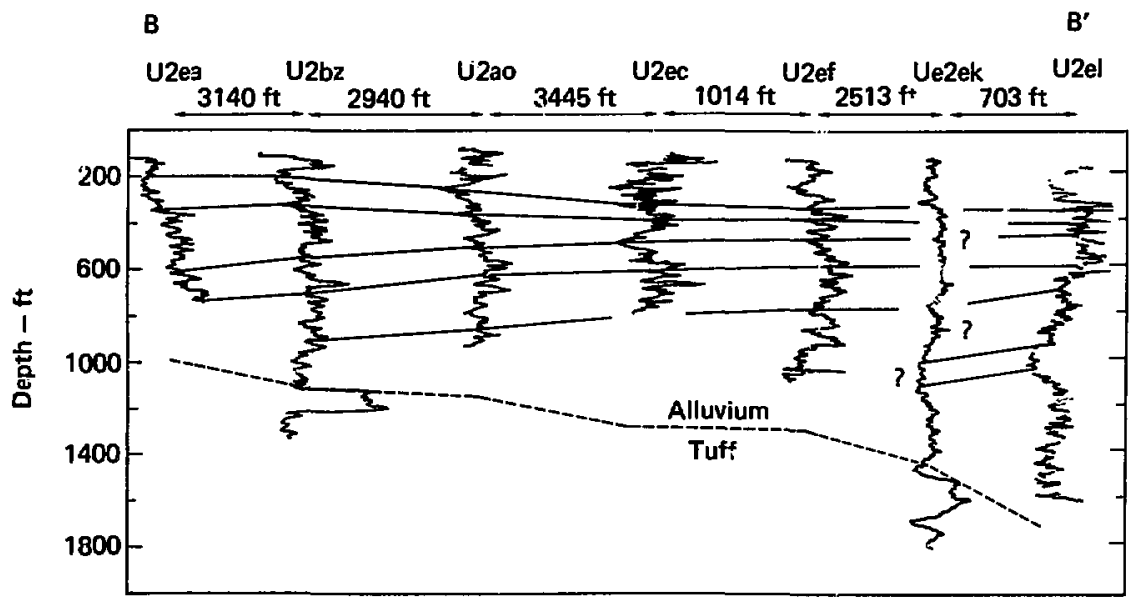

Fig. 6. Resistivity profiles from boreholes along cross section B-B'。 


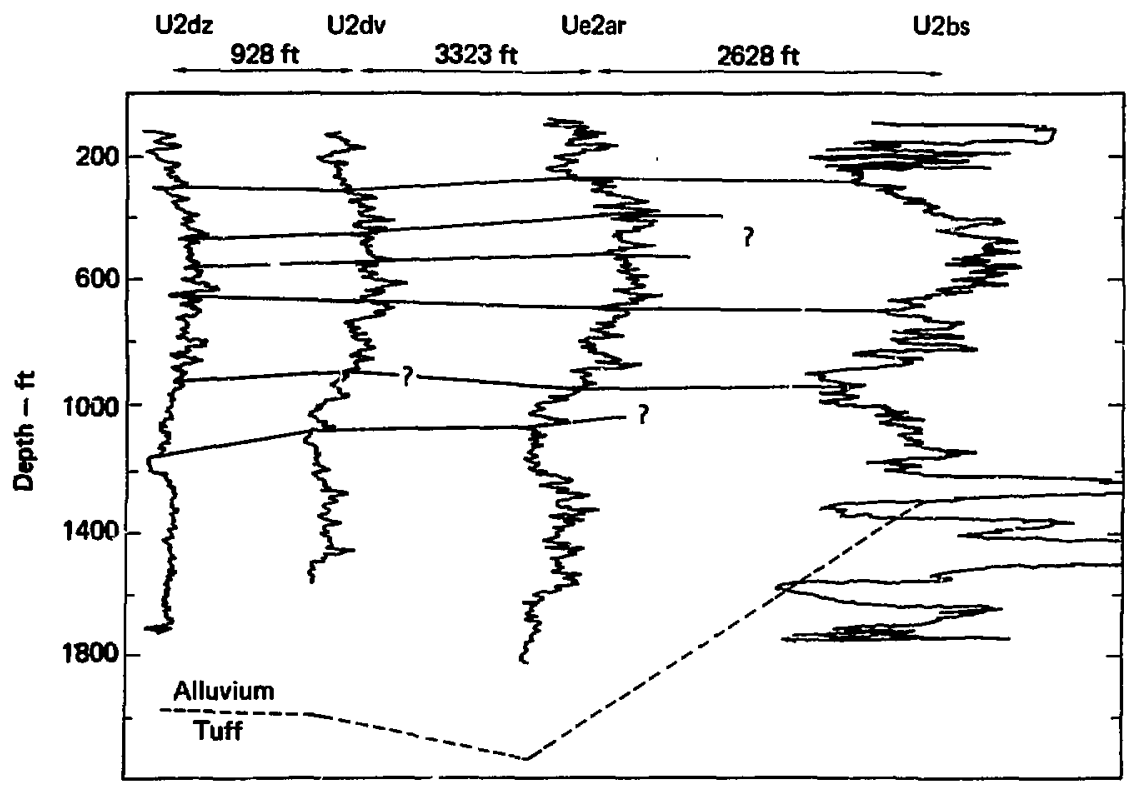

Fiç. 7. Resistivity profiles from boreholes along cross section $C-C^{\prime}$.

If this is true, then the gravity-inferred faults on the Paleozoic surface and faults identified or proposed in the underlying tuffs probably do not penetrate into the alluvium any appreciable distance, if at all.

There does seem to be a greater ease of correlation in $>$ north-south direction than in an east-west direction, at least in the southern part of Area 2, based on our limited number of observations. This phenomenon is interesting in view of the present drainage patterns for Area 2 at Yucca Flat (Fig 8). Those holes we studied are all within the present drainage boundaries of a large fan originating in Rainier Mesa (A in Fig. 8). The massive area of this fan reflects an equally large drainage-basin area. ${ }^{3}$ If we assume that conditions of deposition have been generally the same in the past inasmuch as this fan has been contributing the greatest flux of sediment to this area, then correlating alluvium is much easier north-south than east-west. Bull ${ }^{4}$ has shown that the stratigraphy along radial sections of a fan is

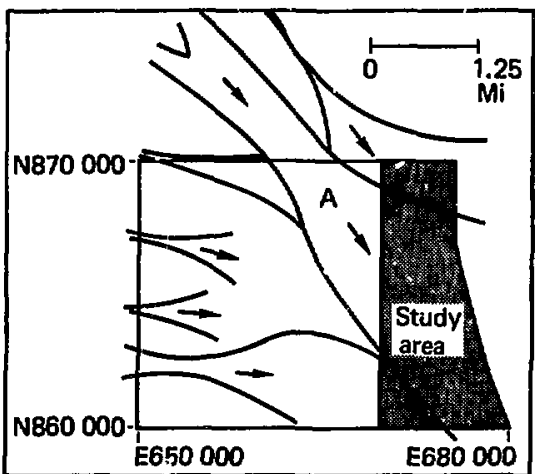

Fig. 8. Gemeral surficial drainage pattem tor Area 2 interpreted from aerial photographs. Numbers around map are Nevada coordinates. 
continuous for greater distances than for sections across a fan.

A much more detailed study of the surficial alluvium divides Yucca Flat into several groups. ${ }^{5}$ They are playa, alluvium, and alluvial-colluvial areas (Fig. 9). The playa deposits are in the area numbered I, and the alluvial depusits arc labeled II th:ough IX. The alluvial-colluvial units are assigned letters A-G.

The dra. Iage pattern for Yucca Flat as a whole is similar to that of Area 2. There are two components to the direction of flow: one toward the distal

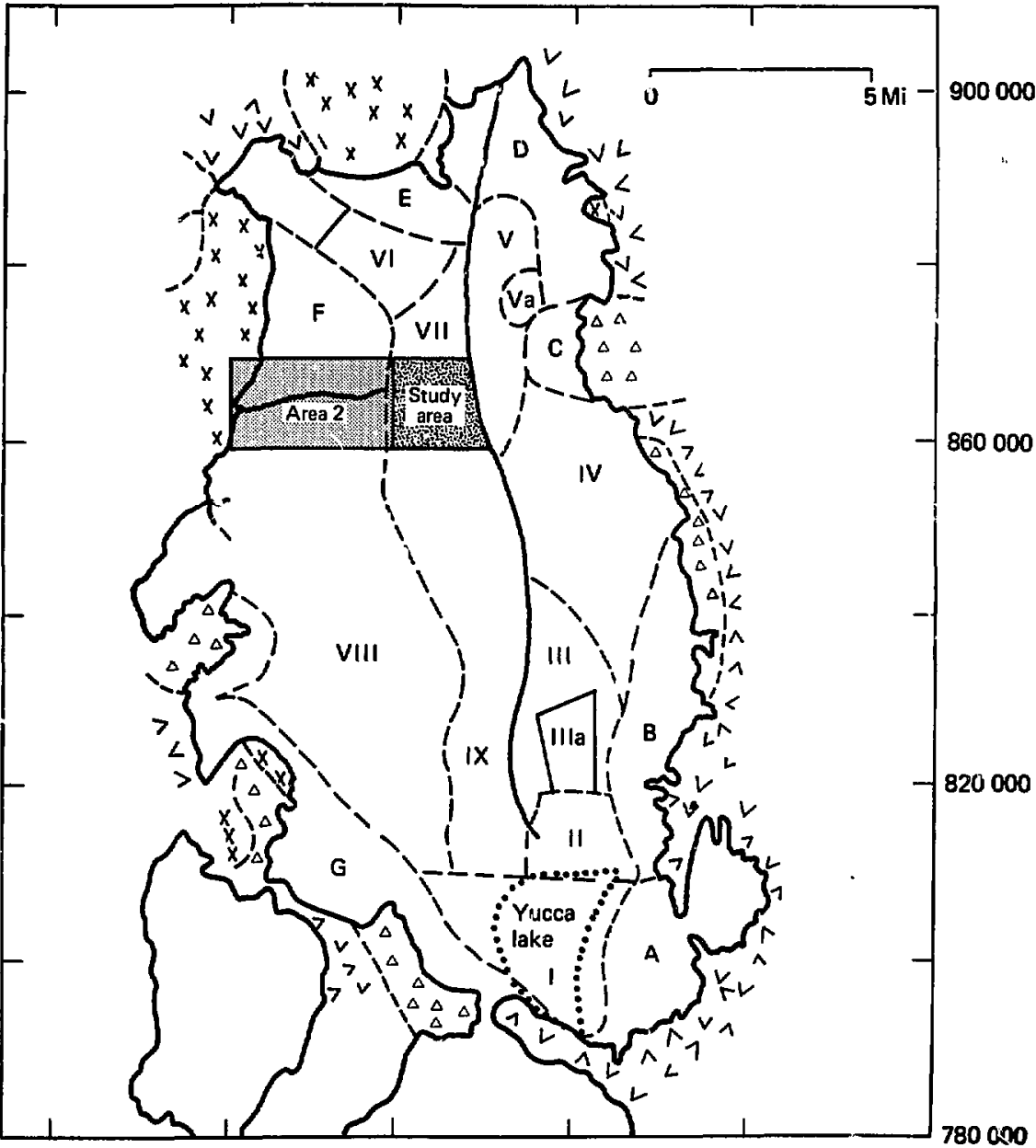

Fig. 9. Map of Yucca Flat showing surficial units. Roman numerals represent alluvial uniits, letters represent alluvial-colluvial units. Numbers around map are Nevada coordinates. 
portions of all contributing arms (towards the center of the basin), and on a larger scale, one main somponent towards the south-east, approaching Yucca Playa. We can therefore expect that this drainuge pattern will decrease the size of particles in the fan at the center and southeast of Yucca Flat. Studies of particle size in alluvial fans of arid regions have shown that the particle size decreases with increasing distance from the fan apex. ${ }^{6}$ The evidence to support this lies in the Area 3 "sandpile", southeast of Area 2. Here, particles are much finer in average clast size and are more uniform than those from Area 2.

\section{Other Methods for Correlating Alluvial Layers}

\section{Comparison of $\mathrm{CO}_{2}$ Percentages}

The distribution of various pebble types in the alluvial strata may be such that distinct lithologies cannot be correlated between holes, but the relative percentage of different rock types may vary enough between fass that a comparison of mineral contents could be used to distinguish fans. Alluvial fans commonly contain minerals such as gypsum and calcite. These are deposited along with the fan either as limestone and dolomite fragments, or as carbonates from surface weathering and reprecipitation frem downward-moving surface water (caliche). $\mathrm{CO}_{2}$ wt\% analyses reflect the combined amount of carbonate contributed to the fans from both sources. Since each fan is the product of a single stream, the mineral content of even adjacent fans may vary greatly from each other if the lithology of their respective source areas is different. ${ }^{7}$

If fans were buried below the water table, the zonation of minerals could be altered, but this is a

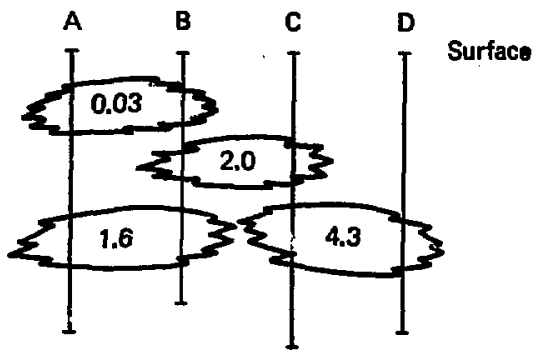

Fig. 10. Schematic representation of how buried fans wight be ileutified based on their $\mathrm{CO}_{2}$ content. Numbers are $\mathrm{CO}_{2}$ content in $w t$ to. rare occurrence at the NTS because the water table is deep. Figure 10 roughly illustrates how a series of buried fans might look along a vertical plane normal to the main fan axes. The question has arisen wheiher or not $\mathrm{CO}_{2}$ sample analyses from drillholes could be used to delineate the subsurface boundaries of fans at the NTS. Several $\mathrm{CO}_{2}$ samples are commonly taken from each hole, and therefore data is available. However, except for the most recently logged holes, the analyses were run only within those zones we were interested in at the time.

Aside from the work by Carlson and McKague ${ }^{8}$ and Germain, ${ }^{9}$ there has been little work with determining subsurface trends in the $\mathrm{CO}_{2}$ content. By averaging the values from each hole and plotting them on a location map, Germain found that there was an overall increase in $\mathrm{CO}_{2}$ toward the north of Yucca Flat. By contrast, the research of Carlson and McKague in Area 2 indicates increasing $\mathrm{CO}_{2}$ concentrations in the deeper tuffaceous alluvium, towards the west and south of Yucca Flat. Even if either of these situations reflects the accurate subsurface conditions, they still do not help us in understanding the stratigraphic geometry of individual fans. As illustrated in Fig. 10 , an average $\mathrm{CO}_{2}$ value ( $w t \%$ ) from vertical sampling may be the result of an average value from two or more buried fans. Thus, we could not rely upon the information to aid us in distinguishing individual alluvial fans.

To use the $\mathrm{CO}_{2}$ data for correlating alluvium strata, another approach would be to areange the $\mathrm{CO}_{2}$ values from the data bank for each hole in columns, as they are listed on computer printouts. Each data point in the column should indicate both the value and the depth from which the reading was made. The values could then be used like a vertical sequence of rock types, and in a correlation (Fig. 11), one may be able to delineate the 3-dimensional limits of distinctive alluvial layers. It is unlikely that

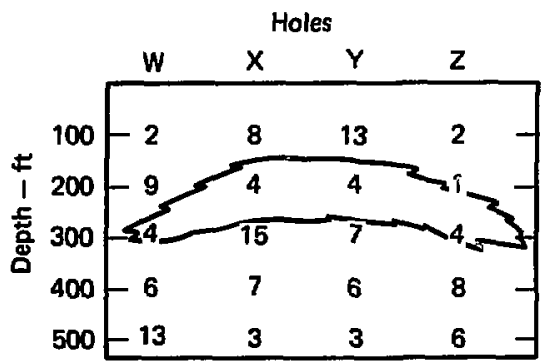

Fig. 11. Hypothetical method of correlating fans by their $\mathrm{CO}_{2}$ wto ralues. 
these values could be contoured as easily as illustrated in Fig. 11, but through examination of the data, we found percentage intervals ( 0 to $2.5 \%, 2.5$ to $5 \%$, etc.) that can be traced between holes. However, a wider coverage of $\mathrm{CO}_{2}$ sampling will be needed before this method can be adequately evaluated.

\section{Caliche Dating}

Uranium age-dating of caliche deposits as a niethod of correlating strata is currently being evaluated. ${ }^{10}$ This process has been successful in dating carbonate coatings from alluvium pebbles, and it has been suggested that the method may be useful in correlating subsurface alluvial fan strata. However, caliche dating poses problems. Without physically testing its applicability, the method may be limited. One limitation is that the carbonate to be tested cannot be greater than 300,000 years old since the products of radioactive decay reach equilibrium after that time.

Aside from this, there are other problems to consider. Because a number of adjacent fans can experience the same climatic influences at the same time, it is logical that they would alt be relatively close in age at any designated horizon. This method would then be of little value in differentiating lateral fan boundaries, although the dating would serve as a paleogeomorphic marker. However, an alluvial fan is deposited such that only a small portion of its surface is active at any time. Thus, the fan head may develop a caliche soil horizon while its distal portion accumulates sediment. This process and the fact that the locus of fan deposition tends to shift with time, may cause different portions of the fan to develop caliche deposits of different ages at the same stratigraphic level. This problem could be further compounded by the retention of previously formed carbonate rinds on pebbles eroded from older fans and redeposited in younger ones. Because of these phenomena, this method would provide similar dates for fans of different ages.

\section{Debris-Flow Deposits}

Another source of data that may be generally useful in correlating fans would be the occurrence of debris-flow deposits. The rationale in using this method is that the occurrence of such deposits would reflect an overall climatic trend and thus serve as a type of local time horizon. By their nature, debris flows are deposited in a short time (minutes to hours) over a relatively large area. In the context of our problem debris flows are produced by short, irregular periods of intense rain- fall along with steep, poorly vegetated slopes and a source that provides a mud matrix. ${ }^{4}$ These deposits are most prevalent near the fan apexes, and have a high density and viscosity compared with streamlaid deposits. Commonly, debris-flow deposits have the following criteria: poorly sorted material, angular and randomly oriented clasts floating in a much finer matrix, and occasionally cracked fragments transported without much displacement. Examination of sidewall stereo photographs allows us to identify such deposits in some cases. Photographs were taken using a downhole camera specifically developed at the Lawrence Livermore Lahoratory for large holes (Fig. 12). This system takes color stereo photographs either of the sidewall or downhole, and can be oriented by its magnetic compuss. Color and stereographic photographs are invaluable to the geologist in determining the lithologic characteristics of the drillhole. Although this system has been in use for more than 10 years, only recently has it been used routinely for all large-diameter drillholes.

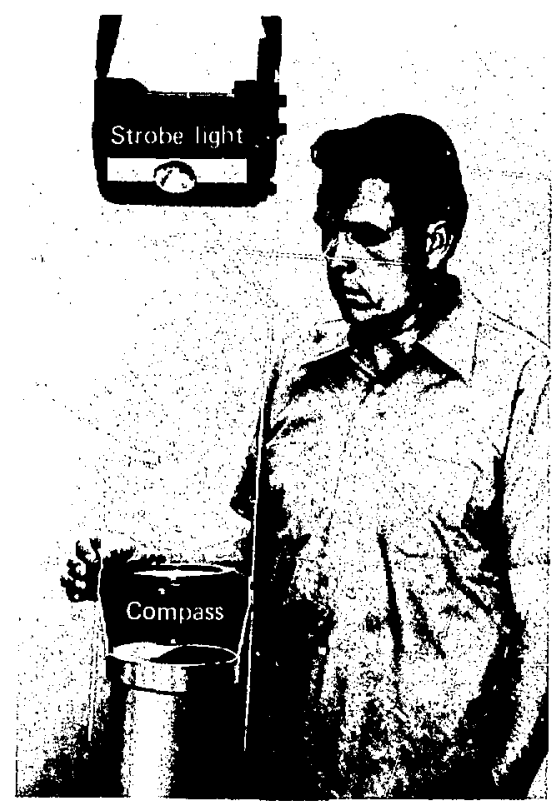

Fig. 12. The downhole stereo camera developed at Lawrence Livermore Laboratory. 

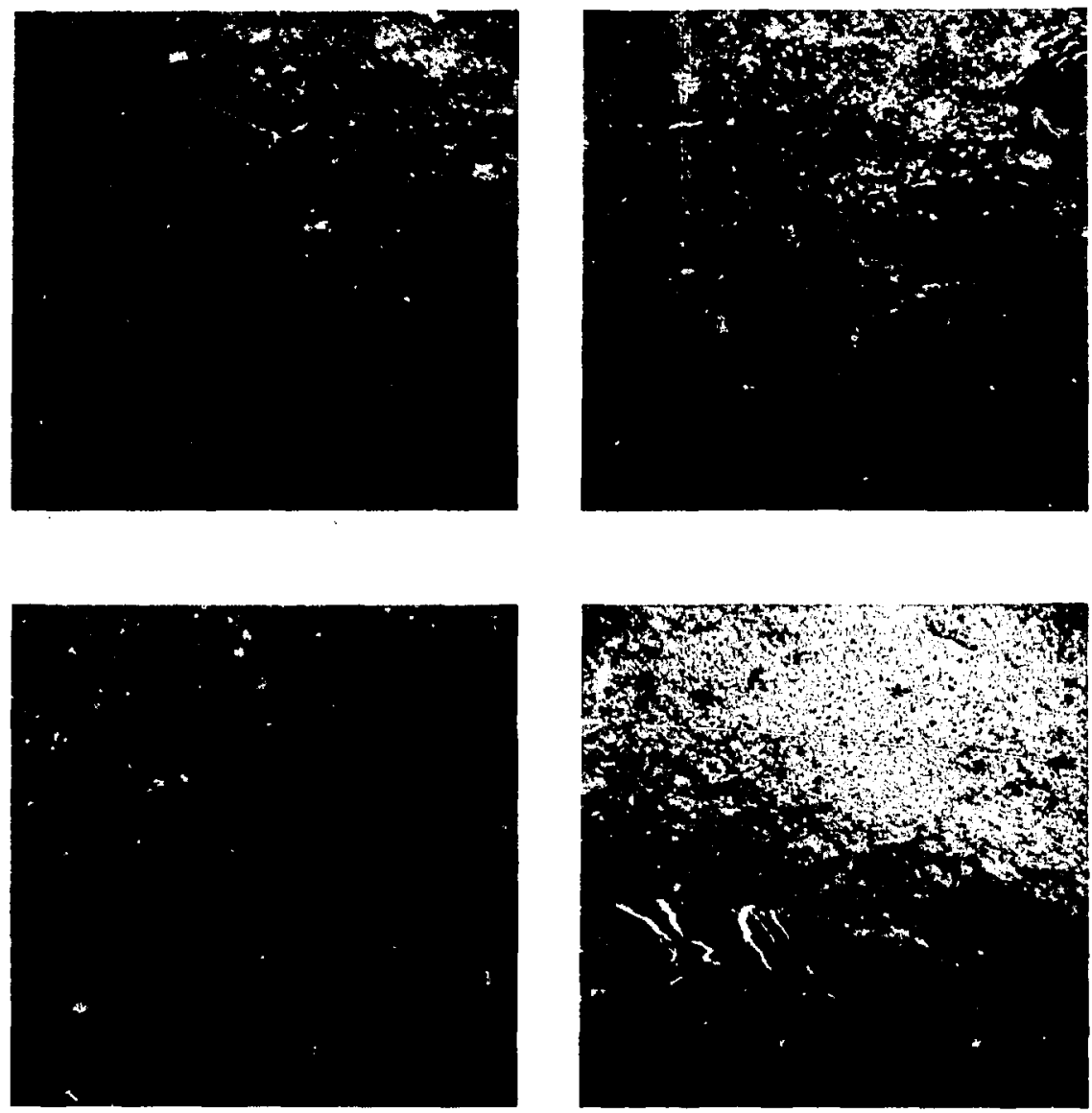

Fig. 13. Fonr views 90' apart of hole U24y at approxinately 1600 ft showing debris flow deposits.

Deposits with most of the criteria of a debris-flow have been seen in at least two and possibly three of five holes in the U2d area from which sidewall photos were available. Pictures from the bottom of hole U2dv at approximately $1600 \mathrm{ft}$. indicate debris flow deposits (Fig. 13). The lower right photograph in this figure shows this particularly well. A large cobble at the bottom of the photograph appears to have been broken and transported with little displacement. In hole U2do, cobbles of Paleozoic: carbonates are prevalent from 854 to $110 \mathrm{ft}$, and most look like a debris flow at $914 \mathrm{ft}$ (Fig. 14), In hole U2dh-3, (Fig. 15) large clasts occur between 800 and $900 \mathrm{ft}$ and are especially coarse between 850 and 860 $\mathrm{ft}$. Based on the limited number of sidewall photos available from the older holes, it is difficult to assess whether plotting the occurrence of such deposits is a useful correlation method. The few sidewall photographs we have prevent us from determining whether flows intersect many of the holes. From the photographs we have, it appears that debris flows are limited to the west side of the Area 2, implying 


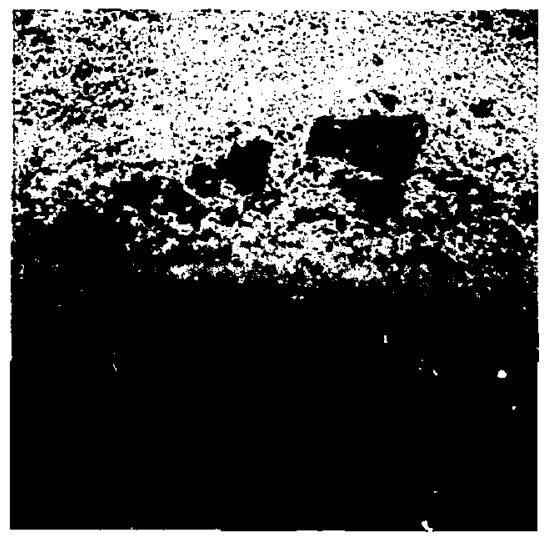

Fig. 14. Three views of hole U2do at approximstely 914 ft showing debris fow deposits.
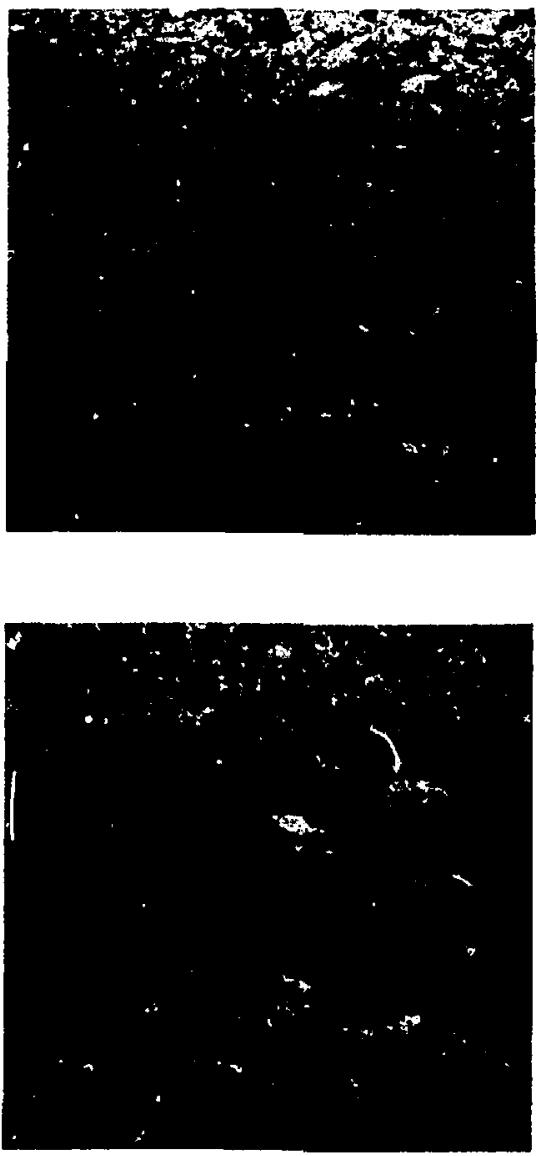

hard or too large for the sidewall tool to penetrate. The occurrence of such high values from these holes may be attributed to similar zones.

\section{Specific Yield and Permeability}

Another possible method of correlating subsurface alluvium is by specific yield and permeability measurements. Specific yield is the ratio of gravityyielded water from a saturated rock to the volume of the rock. There has been some success in accomplishing this by Magleby and Klein. "1 These workers were able to correlate alluvial fan deposits in Central California by using these parameters. 

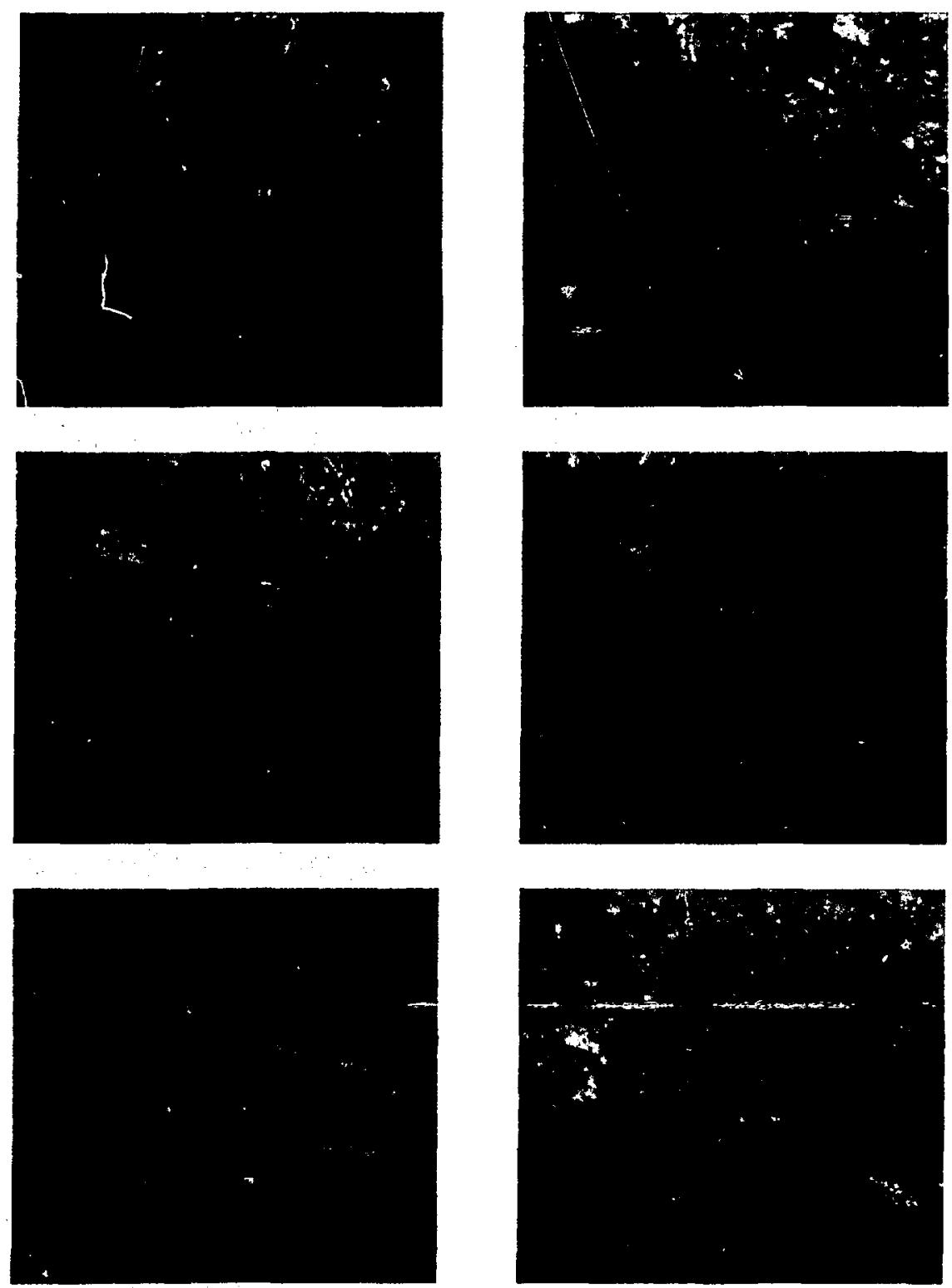

Fig. 15. Vkews at increailes dephs to 860 fi of bole U2dh-3 showing outlines of tuff and limestone (IS) clests. 
Croft ${ }^{12}$ developed a method for extracting specific yield and permeability data from electric logs taken in the conventional manner, but this process cannot be applied to the electric log data of Yucca Flat because of a lack of formation saturating fluid and the hole drilling techniques used at the Test Site.
Normally, values of spontaneous potential would provide sufficient permeability data. However, even though spontaneous potential is commonly logged together with resistivity at the NTS, this information is not helpful as there is so little variability in the readings.

\section{SUMMARY AND CONCLUSIONS}

Although not an easy task, correlation of the alluvium at the NTS is possible, and zones within t... Uluvium appears to be more continuous than $\therefore$. ht before. Comparison of large changes in the $\therefore$ of resistivity curves with an alluvium zonation $\therefore$ ised by Germain using water content, grain density, anil bulk density indicates a similarity in certain zones. This suggests that the occurrence of such bow-shajed resistivity curves can be used to predict relative changes in density and saturation with depth. Further, from the similarity of such curves, the zonal interactions among these three parameters must be similar throughout the study area.

On a smaller scale, even the kicks in resistivity logs can be correlated easily in most cases, but the complexity of the alluvium makes it difficult to interpret the meaning of these correlations. Smallscale fluctuations may be due mainly to the interaction of these three parameters, but the many factors that determine the effective porosity (lithology, grain size, particle roundness, etc.) all contribute to the resistivity values. Although the major trends in resistivity may be determined mainly by the interaction of water content, grain density, and bulk density, minor changes in resistivity trends probably represent the interaction of many other factors as well.

Based on resistivity îgs from Area 2, we found that the major vertical zones of alluvium are con- tinuous with only minor changes occurring over great distances, especially in a north-south direction. Other than the major Yucca and Carpetbag faults, tectonic activity in this area was minor or occurred prior to deposition of the alluvium.

Two other methods for correlating the Yucea Flat alluvium layers appear promising. One of these-comparison of $\mathrm{CO}_{2}$ percentages-is worth pursuing for two reasons. First, alluvial fans are characteristically fed by single streams with a definite drainage area. Thus, the mineral content precipitating from their waits as they reach the fans should be unique from one fan to another. Second, even if the $\mathrm{CO}_{2}$ content cannot be used to distinguish fan boundaries, any information on subsurface trends in $\mathrm{CO}_{2}$ would be valuable for future site selection.

Another method that may help in correlating alluvial fans is comparison of the stratigraphic levels at which debris flow deposits occur. Such deposits have been seen in Area 2 boreholes by use of stereo photography. Photo coverage is sparse, however, and more data will be needed before the efficiency of the method can be determined.

Although we may never be able to precisely correlate the alluvium of Yucca Flat, we are closer now to this goal than before, and further research into these methods is needed to complete our task.

\section{ACKNOWLEDGMENT}

This work was performed under Lawrence Livermore Laboratory's Summer Program for students. This project was originally proposed by $\mathrm{H}$. Lawrence McKague. The authors wish to thank Dr. McKague and Richard C. Carlson for their useful discussions and comments about the project. The $\mathbf{E}$ log comparison plots were produced by Edward Hwang and Jerome Richter of EG\&G, San Ramon, CA, who developed the Geophysical Data System at LLL. Lithnlogic interpretation of some of the downhole photographs was detailed by Richard D. McArthur of LLL in Mercury, Nevada. 


\section{REFERENCES}

1. A. T. Fernald, G. S. Corchary, W. P. Williams, and R. B. Colton, "Surficial Deposits of Yucca Flat Area, Nevada Test Site," in Nevada Test Site, Memoir 110 (The Geological Society of America, Inc., 1968), pp. 49-55.

2. L. S. Germain, NTS Alluvium II: Water Content, Grain Density and Bulk Density in A reas 2 and 10, Los Alamos Scientific Laboratory, Los Alamos, N M Office Memorandum (May, 1976).

3. W, B. Bull, Geomorphology of Segmented Alluvial Fans in Westem Fresno Countv, California, U. S. Geological Survey, Menlo Park, CA, 352-E, pp. 89-129 (1964).

4. W. B. Bull, Recognition of Alluvial Fan Deposits in the Stratigraphic Record, Society of Economic Paleciltologists and Mineralogists, Tulsa, OK, Special Publication \#16 (1972).

5. A. T. Fernald, Nevada Test Site, private communication (1974).

6. E. Blissenbach, "Geology of Alluvial Fans in Semiarid Regions", Geol. Soc. American Bull. 65, 175 (1954).

7. W, B. Bull, Alluvial Fans and Near-Surface Subsidence in Western Fresno County, Califormia, U. S. Geological Survey, Menlo Park, CA, 437-A (1964).

8. R. C. Carlson and H. L. McKague, Distribution of $\mathrm{CO}_{2}$ in Tuffaceous Alluvium of Area 2, Lawrence Livermore Laboratory Memorandum UOPKB 75-15 (1975).

9. L. S. Germain, NTS Alluvium IV: Carbon Dioxide Confent in Southern Yucca Valley, Los Alamos Scientific Laboratory Los Alamos, NM Office Memorandum, (1977).

10. K. Knauss, "Th 230/U 234 Dating of Alluvial Pedogenic Carbonates", Geolog. Soc. Amer. Abstr. 9 (7); 1061 (1977).

11. D. C. Magleby, and I. E. Klein, 1965, Ground-Water Conditions and Potential Pumping Resources Above the Corcoran Clay, Appendum to the Ground Water Geology and Resources Definite Plan Appendix, U. S. Bur. Reclamation open-file report (1963).

12. M. G. Croft, A Method of Calculating Permeability from Electric Logs, U. S. Geological Survey, Menlo Park, CA, Rept. 750-B (1971).

\section{BIBLIOGRAPHY}

The following references will provide readers with further information about the correlation of alluvial deposits of the NTS.

H. Barnes, E. N. Hinricks, F. A. McK eown, P. O. Orkild, U. S. Geological Survey Investigations of Yucca Flat, Nevada Test Site, Part A: Geology of Yucca Flat Area, U. S. Geological Survey, Denver, CO, Technical Letter NTS-4.5 (1963).

P. Cohen, Stratigraphy and Origin of Lake Lahontan Deposits of Humbolt River Valley Near Winnemucca, Nevada, U. S. Geological Survey, Washington, D. C., Professional Paper 450-C (1962).

R. M. Hazelwood, D. L. Healey, C. H. Miller, U. S. Geological Survey Investigations of Yucca Flat, Nevada Test Size, U. S. Geological Survey, Denver, CO, Technical Letter NTS-45 (1963).

R. B. L. Hooke, "Processes on Arid-Region Alluvial Fans in Closed Basins," Am. J. Sci. 266, 609 (1967).

S. A. Schumm and R. S. Parker, "Implications of Complex Responses to Drainage Systems for Quarternary Alluvial Stratigraphy", Nature Physical Science 243, 99 (1973).

R. P. Snyder, "Flectric and Caliper Logs as Lithographic Indicators in Volcanic Rocks, Nevada Tesc Site", in Nevada Test Site, Memoir 110 (The Geological Society of America, Inc., 1968), pp. 117-124.

W. P. Williams, W. L. Emerick, R. E. Davis, R. P. Snyder, Geological Survey Investigations in Yucca Flat, Nevada Test Site, Part C. The Underground Test Media of Yucca Flat, U. S. Geological Survey, Denver, CO, Technical Letter NTS-45 (1963). 